\title{
Effects of light intensity on the distribution of anthocyanins in Kalanchoe brasiliensis Camb. and Kalanchoe pinnata (Lamk.) Pers
}

\author{
BRUNA P. CRUZ ${ }^{1}$, LUCIANA M. CHEDIER ${ }^{1}$, PAULO H.P. PEIXOTO ${ }^{1}$, \\ RODRIGO L. FABRI ${ }^{2}$ AND DANIEL S. PIMENTA ${ }^{1}$ \\ ${ }^{1}$ Departamento de Botânica, Instituto de Ciências Biológicas, Universidade Federal de Juiz de Fora, \\ Rua José Lourenço Kelmer, s/n, São Pedro, 36036-900 Juiz de Fora, MG, Brasil \\ ${ }^{2}$ Departamento de Bioquímica, Instituto de Ciências Biológicas, Universidade Federal de Juiz de Fora, \\ Rua José Lourenço Kelmer, s/n, São Pedro, 36036-900 Juiz de Fora, MG, Brasil
}

Manuscript received on November 22, 2010; accepted for publication on June 29, 2011

\begin{abstract}
This paper compares two medicinal species of Kalanchoe, which are often used interchangeably by the population, regarding the distribution of anthocyanins under the influence of four luminosity levels for 6 months. For the morphoanatomical analysis, the 6th stem node of each plant was sectioned. Usual histochemical tests revealed the presence of anthocyanins by cross sections of the stems, petioles and leaf blades. The petioles and leaf blades were submitted to the extraction with acidified methanol, and the anthocyanins were quantified by spectrophotometric readings. At the macroscopic level, it was noticed for both species a higher presence of anthocyanins in stems and petioles of plants under full sunlight. The microscopy of $K$. brasiliensis stems evidenced the deposition of anthocyanins in the subjacent tissue to the epidermis and cortex, which increased with light intensity. In $K$. pinnata a subepidermal collenchyma was observed, which interfered in the visualization of anthocyanins. In petioles and leaf blades of $K$. brasiliensis the deposition of anthocyanins was peripheral, and in K. pinnata it was also throughout the cortex. The quantification of anthocyanins in petioles showed in $70 \%$ of light higher averages than in $25 \%$, but in leaf blades there were no significant results. This study contributes to the pharmacognosy of Kalanchoe and it is sustained by the description of flavonoids as biological markers of the genus.
\end{abstract}

Key words: Anthocyanins, Kalanchoe, luminosity, vegetal anatomy.

\section{INTRODUCTION}

Anthocyanins are important pigments from vascular plants. They are responsible for the orange, pink, red, violet and blue colors of the flowers and fruits of some plants (Castañeda-Ovando et al. 2009) and are mainly used as food colorings in the beverage industry (He and Giusti 2010).

Correspondence to: Daniel Sales Pimenta

E-mail: daniel.pimenta@ufjf.edu.br
An important medicinal property of the anthocyanins is the antioxidant activity, which plays a vital role in preventing neurological and cardiovascular diseases, cancer and diabetes, among others (Castañeda-Ovando et al. 2009). Because of this, new naturally occurring antioxidants, especially those isolated from medicinal plants, acquire great pharmacological importance, and many researches on these compounds have been widely developed in recent years (Silva et al. 2009). Anthocyanins 
are flavonoids that have the flavan nucleus as the basic structure, and are characterized by being water - soluble compounds. Their biosynthesis and accumulation depend on factors such as light, temperature, nutritional status, hormones, mechanical damage and pathogen attacks. Light is the most important external factor in their biosynthesis by indirect photoactivation of the involved enzymes through the phytochrome system. The stability of anthocyanins is affected by their chemical structure, concentration and $\mathrm{pH}$, among other factors (Cruz 2008, Kong et al. 2003).

Kalanchoe (Crassulaceae) comprises about 125 species, including Kalanchoe brasiliensis Camb. and Kalanchoe pinnata (Lamk.) Pers, which are medicinal species known respectively as "saião" and "folha da fortuna" (Costa et al. 2008) and are used throughout the country to treat coughs, boils, gastritis and adnexitis (Lorenzi and Matos 2008).

$K$. brasiliensis is a perennial herb native to Brazil, which reaches from $30 \mathrm{~cm}$ to $1 \mathrm{~m}$ height. Its leaves are oval, opposite, fleshy, simple and short-petiolate, and the herbaceous stem is cylindrical. $K$. pinnata is a subligneous plant native to Madagascar, perennial, up to $150 \mathrm{~cm}$ height. It presents oval, fleshy, simple and compound leaves with crenate margins and long petioles, and their stems are four-angled (Veiga Jr. 2005) (Figs. 1a and 1b). Both species have been little studied, and despite

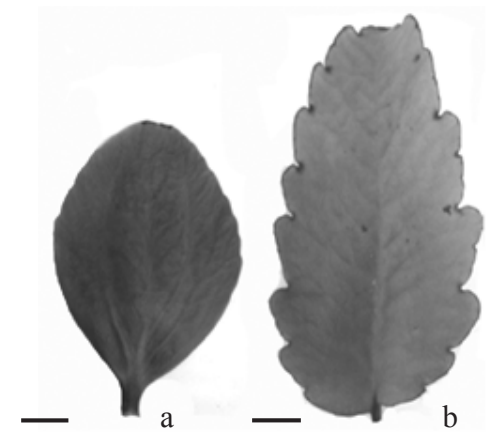

Fig. 1 - Leaf of Kalanchoe brasiliensis (a) and terminal leaflet of Kalanchoe pinnata (b). Bars $=10 \mathrm{~mm}$ having different morphological characters, they are often used interchangeably by the population (Costa et al. 2008). In previous studies the same species showed considerable differences in the agronomic development (Cruz et al. 2011). The aim of this study was to identify the microscopic and macroscopic effects of light intensity on the distribution of anthocyanins in stems, petioles and leaf blades of both species, as well as quantify the anthocyanins content in petioles and leaf blades.

\section{MATERIALS AND METHODS}

\section{Plant Material AND Growth CONDITIONS}

Seedlings of the studied species at the same stage of development, which were obtained in a garden of the Faculdade de Farmácia e Bioquímica, Universidade Federal de Juiz de Fora (UFJF), Brazil, were planted in plastic bags with 51 of homogeneous substrate consisting of soil/sand/manure (3:1:1) and placed in a botanical station at Universidade Federal de Juiz de Fora, Brazil. Voucher specimens (K. pinnata: 46575 / K. brasiliensis: 43980) are kept in the Herbarium Leopoldo Krieger (CESJ) of UFJF. The plots were grown under four light levels $(25 \%, 50 \%, 70 \%$ and full sunlight) at environment temperature for about 6 months using black screens of polyethylene, shade type. With one plant per plot, the four treatments were randomly evaluated in six replications, resulting in 24 plots per species and a total of 48 plots.

\section{MeAsurements ANd ANALYTiCAL Determinations}

For morphoanatomical evaluations of stems and leaves, the 6th node, referring to the stem apex of each plant, was taken from cross sections in the middle portion of the 5th and 6th internodes. The sections were photographed with a digital camera (Sony Cybershot, Optical Zoom 4x, 7.2 Megapixels) to define the macroscopic patterns of distribution of anthocyanins in stems, petioles and leaf blades. 
The anatomical characterization of the stems was performed with freehand cross sections of the fresh 5th internode. Leaves collected at the 6th node were evaluated from freehand cross sections of fresh petioles and leaf blades; for that, cuts were standardized in the median portions and midribs, respectively. Initially, classical histochemical tests were performed according to Kraus and Arduin (1997) in fresh cross sections of petioles and leaf blades. The reagents used were: $10 \%$ ferric chloride for phenolic compounds; lugol (1g of potassium iodide, $1 \mathrm{~g}$ of iodine and $100 \mathrm{ml}$ of distilled water) for starch; $0.02 \%$ ruthenium red for mucilage; $0.5 \%$ Sudan III in $80 \%$ ethanol for lipophilic components, and for anthocyanins a $\mathrm{pH}$ variation with $\mathrm{HCl}$, followed by $\mathrm{Na}_{2} \mathrm{CO}_{3}$ P.A., was induced (Torskangerpoll and Andersen 2005). Due to the relevance of the presence of anthocyanins, all 48 plots were evaluated by fresh sections prepared on semi-permanent slides and photographed with a light microscope (Olympus BX-41) coupled with a digital camera to obtain the microscopic patterns of distribution of anthocyanins.

The petioles and leaf blades of the 6th node opposite to those used in the methodology described above for the treatments of 70, 50 and $25 \%$ of light were used to quantify the anthocyanins content. The extraction was performed according to the method of Mancinelli (1990) with slight modifications. It was used $1 \mathrm{~cm}$ of petiole, as well as $1 \mathrm{~cm}^{2}$ of the middle and intercostal portions of leaf blades for extraction by maceration in acidified methanol with $1 \% \mathrm{HCl}$. The absorbances were read in the ELISA spectrophotometer at $530 \mathrm{~nm}$ (maximum absorption of anthocyanins) and $657 \mathrm{~nm}$ (maximum absorption of the degradation products of chlorophylls in acid methanol). Three samples were used per species/ treatment, and the readings were performed in triplicate. The formula $A 530-0.25 A 657$ was used to compensate the contribution of the degradation products of chlorophylls to the absorbance at
$530 \mathrm{~nm}$. The total content of anthocyanins was estimated as cyanidin-3-glucoside using a molar absorptive coefficient of $26.900 \mathrm{~L} \cdot \mathrm{cm}^{-1} \cdot \mathrm{mg}^{-1}$ and a molecular weight of 449.2g/mol (Mota 2006).

The results were analyzed by ANOVA, followed by the Tukey test. The data were described as significantly different, with $5 \%$ of significance.

\section{RESULTS AND DISCUSSION}

The secretory structures found in stems, petioles and leaf blades of both species consisted of idioblasts containing anthocyanins. Costa et al. (2008) reported several classes of flavonoids isolated from species of Kalanchoe, including anthocyanins, but there are no reports of these substances in K. brasiliensis and K. pinnata. For these species the authors mentioned the presence of flavonols and flavones and reported the bioactivity of the flavonoid quercetin. The present study evaluates the content of this chemical class and its anatomical location for both species.

\section{MACROSCOPIC DESCRIPTION}

In relation to the cultivation of both species under four light intensities, it was observed a higher presence of anthocyanins in stems and petioles of plants grown under full sunlight. Figures 2 and 3 show results that corroborate the photoprotective effect with an emphasis on the

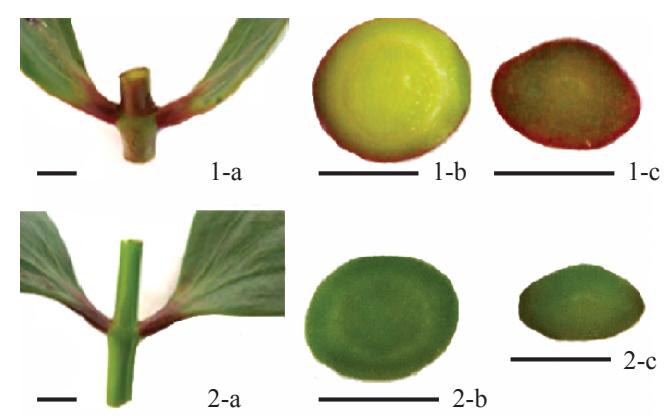

Fig. 2 - Sections of stems (1-a, b) and petioles (1-c) of Kalanchoe brasiliensis seedlings under full sunlight and $25 \%$ of light (stem: $2-\mathrm{a}, \mathrm{b}$; petiole: $2-\mathrm{c}$ ). Bars $=10 \mathrm{~mm}$ (1-a, 2-a); $5 \mathrm{~mm}$ (1-b,c; 2-b,c). 


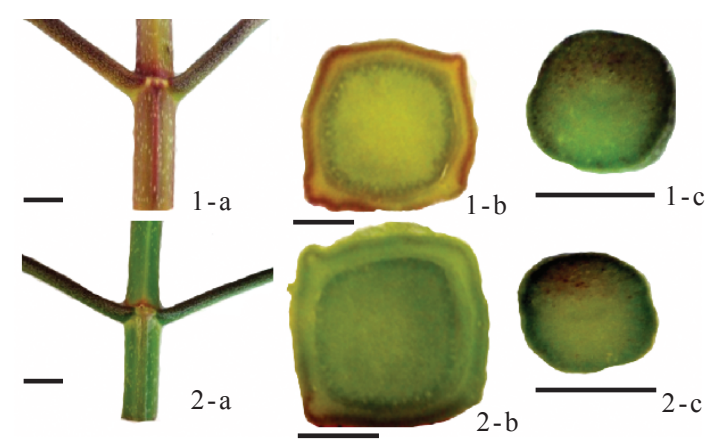

Fig. 3 - Sections of stems (1-a, b) and petioles (1-c) of Kalanchoe pinnata seedlings under full sunlight and $25 \%$ of light (stem: 2-a, b; petiole: 2-c). Bars $=10 \mathrm{~mm}(1-\mathrm{a}, 2-\mathrm{a})$; $5 \mathrm{~mm}(1-\mathrm{b}, \mathrm{c} ; 2-\mathrm{b}, \mathrm{c})$.

peripheral accumulation of anthocyanins in stems and petioles of both species under full sunlight. There is a well-established positive correlation between the intensity of light radiation and the production of phenolic substances such as anthocyanins (GobboNeto and Lopes 2007), which can be explained by their great capacity of light absorption that may be important in protecting plants against the damage induced by UV radiation (He and Giusti 2010).

\section{MICROSCOPIC DESCRIPTION}

Stems

Through the cross sections of $K$. brasiliensis stems it was identified the presence of anthocyanins in both plots grown under full sunlight, 70, 50 and 25\% of light, although they have been little visualized in the treatments of lower luminosity (Fig. 4). It was observed as a pattern that the deposition of anthocyanins near the subjacent tissue to the stem epidermis and in the cortex increased proportionally with light intensity.

Regarding the plots of $K$. pinnata, it was observed at a macroscopic level a pattern of anthocyanins deposition proportional to the intensity of light, but the microscopy analysis did not corroborate it. In this species it was observed in the stem sections the presence of a subepidermal collenchyma where the cells are reduced and have thicker walls, which decreases the emphasis for the cytoplasm and hampers the visualization of the deposition of anthocyanins (Figs. 4 and 5).

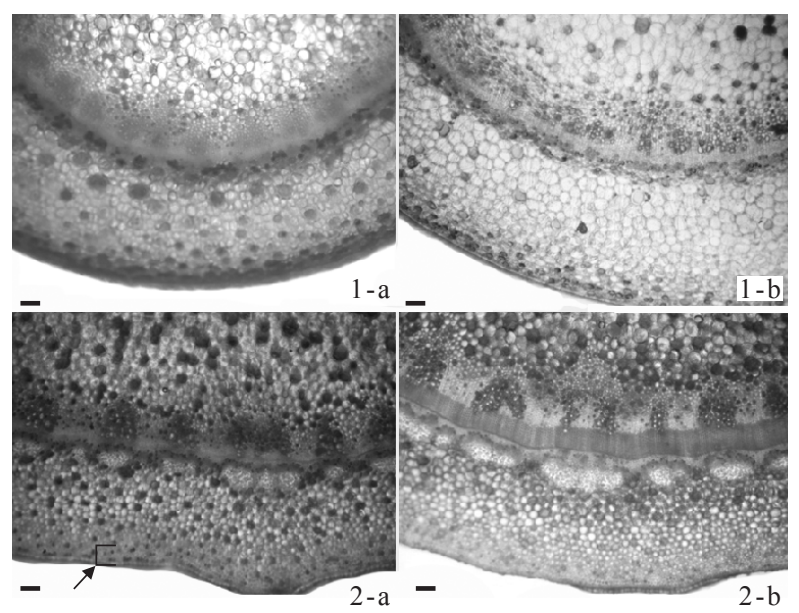

Fig. 4 - Anatomical cross sections of stems of Kalanchoe brasiliensis seedlings (1-a: under full sunlight; 1-b: $25 \%$ of light) and Kalanchoe pinnata (2-a: under full sunlight; 2-b: $25 \%$ of light). Arrow: Detail of subepidermal collenchyma in Kalanchoe pinnata. Bars $=0.1 \mathrm{~mm}$.

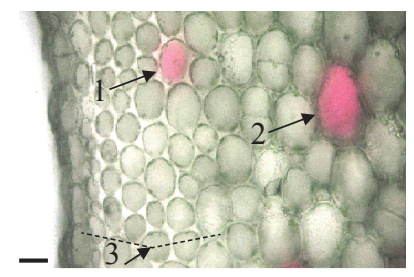

Fig. 5 - Anatomical cross section of the stem of Kalanchoe pinnata seedling grown under full sunlight. Arrow (1): Anthocyanin in collenchyma. Arrow (2): Anthocyanin in parenchyma. Arrow (3): Detail of annular collenchyma in Kalanchoe pinnata. $\mathrm{Bar}=0.05 \mathrm{~mm}$.

\section{Petioles}

The sections of petioles showed greater variation in the distribution of anthocyanins between the two species than that obtained between the treatments (Fig. 6). In K. brasiliensis, the deposition of anthocyanins is peripheral, near the subjacent tissue to the petiole epidermis, but in $K$. pinnata the deposition is peripheral and also throughout the cortex. Figure 6 illustrates this pattern with plants grown under full sunlight. In $K$. brasiliensis it was identified a slight difference in the distribution of anthocyanins between the treatments, with little visual variation, being higher under full sunlight. 


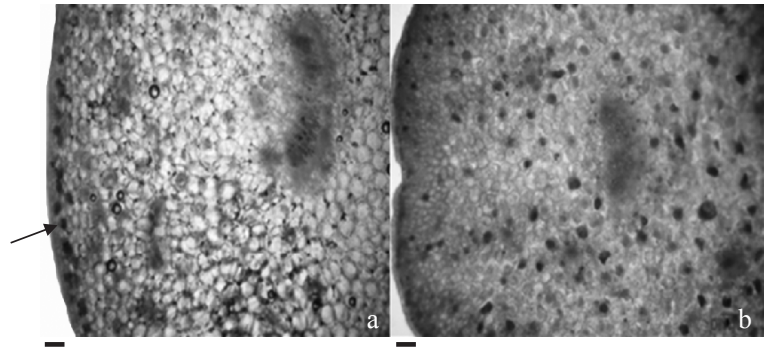

Fig. 6 - Anatomical cross sections in the middle portions of petioles of Kalanchoe brasiliensis (a) and Kalanchoe pinnata (b) grown under full sunlight. Arrow: Deposition of anthocyanins near the subjacent tissue to the petiole epidermis in Kalanchoe brasiliensis. Bars $=0.1 \mathrm{~mm}$.

\section{Leaf blades}

The sections of leaf blades of both species showed the same pattern of anthocyanins deposition observed in the petioles. In K. brasiliensis they were concentrated in the subjacent tissue to the epidermis, and in K. pinnata they were distributed throughout the leaf blade. Figure 7 illustrates this pattern in plants grown under full sunlight.

\section{QUANTIFICATION OF ANTHOCYANINS}

This part of the study has confirmed the photoprotective effect of anthocyanins in petioles since in $70 \%$ of light averages statistically higher than in $25 \%$ of light were obtained by analyzing together both species (Table I). In general, the induction of anthocyanins synthesis requires higher light intensities, and the amount of anthocyanins in plants and individual leaves vary in relation to the light exposure levels (Steyn et al. 2002). In leaf blades no significant results were obtained probably due to the higher concentration of pigments in the leaf margins, being more concentrated in the petiole as seen in Figures 2 and 3.

In the present study, the higher amount of total anthocyanins was obtained for the petioles of Kalanchoe pinnata under $70 \%$ of light $(1.845 \mathrm{mg} / 100 \mathrm{~g})$. This result indicates again the photoprotective effect of anthocyanins in petioles, but it is a low value compared to those obtained by Lima et al. (2003) for the fruits of Malpighia emarginata D.C. (3.79 to $59.74 \mathrm{mg} / 100 \mathrm{~g}$ ) and

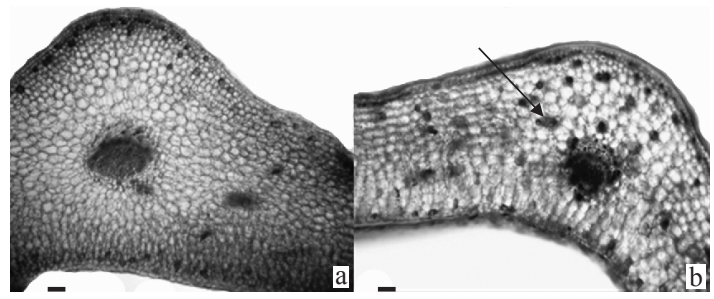

Fig. 7 - Anatomical cross sections near the midribs of the leaf blades of Kalanchoe brasiliensis (a) and Kalanchoe pinnata (b) grown under full sunlight. Arrow: Deposition of anthocyanins in the mesophyll of Kalanchoe pinnata beyond the deposition near the subjacent tissue to the epidermis in both species. Bars $=0.1 \mathrm{~mm}$.

TABLE I

Total anthocyanins content in leaf blades and petioles of plots of Kalanchoe brasiliensis $(\mathrm{Kb})$ and Kalanchoe pinnata $(\mathrm{Kp})$ in treatments (TR) under $70 \%(70), 50 \%(50)$ and $25 \%$ (25) of light.

\begin{tabular}{c|ll|ll}
\hline & & $\begin{array}{l}\text { Anthocyanins } \\
\text { Leaf blade } \\
(\mathbf{m g} / \mathbf{1 0 0 g})\end{array}$ & & $\begin{array}{l}\text { Anthocyanins } \\
\text { Petiole } \\
(\mathbf{m g} / \mathbf{1 0 0 g})\end{array}$ \\
\hline $\begin{array}{c}\text { Total: } \\
\text { Kb } \\
\text { Kp }\end{array}$ & & $0.357 \mathrm{a}$ & & $\begin{array}{l}1.174 \mathrm{a} \\
1.510 \mathrm{a}\end{array}$ \\
\hline & & $0.503 \mathrm{a}$ & $\mathbf{5 5}$ & $1.081 \mathrm{a}$ \\
TR & $\mathbf{5 0}$ & $0.350 \mathrm{a}$ & $\mathbf{2 0}$ \\
& $\mathbf{7 0}$ & $0.463 \mathrm{a}$ & $\mathbf{5 0}$ & $1.251 \mathrm{ab}$ \\
& $\mathbf{2 5}$ & $0.478 \mathrm{a}$ & $\mathbf{7 0}$ & $1.694 \mathrm{~b}$ \\
\hline & $\mathbf{5 0}$ & $0.244 \mathrm{a}$ & $\mathbf{2 5}$ & $0.987 \mathrm{a}$ \\
Kb & $\mathbf{7 0}$ & $0.276 \mathrm{a}$ & $\mathbf{5 0}$ & $0.991 \mathrm{a}$ \\
& $\mathbf{2 5}$ & $0.551 \mathrm{a}$ & $\mathbf{7 0}$ & $1.544 \mathrm{a}$ \\
\hline & $\mathbf{2 5}$ & $0.405 \mathrm{a}$ & $\mathbf{2 5}$ & $1.175 \mathrm{a}$ \\
$\mathbf{K p}$ & $\mathbf{5 0}$ & $0.455 \mathrm{a}$ & $\mathbf{5 0}$ & $1.511 \mathrm{a}$ \\
& $\mathbf{7 0}$ & $0.649 \mathrm{a}$ & $\mathbf{7 0}$ & $1.845 \mathrm{a}$ \\
\hline
\end{tabular}

Averages followed by the same letters in columns do not differ at $5 \%$ probability by Tukey test.

Kuskoski et al. (2006) for various fruit pulps (41.8mg/100g for Morus nigra L.; 30.9 for Vitis vinifera L.; 23.7 for Fragaria vesca L.; 22.8 for Euterpe oleracea Mart.; 2.7 for Psidium guajava L.). This difference is probably due to the intense color of these fruits.

This study shows the influence of the luminosity on the phenotypic plasticity of Kalanchoe species and contributes to the pharmacognosy of the genus and to the reduction of the interchangeably use of both species analyzed. It is important to conclude 
that the analysis of different patterns of distribution of anthocyanins is relevant since it is known that flavonoids are biological markers in Kalanchoe.

\section{ACKNOWLEDGMENTS}

The authors would like to thank "Pró-Reitoria de Pesquisa da Universidade Federal de Juiz de Fora" (PROPESQ-UFJF),"Fundação de Amparo à Pesquisa do Estado de Minas Gerais" (FAPEMIG), "Programa de Pós-Graduação em Ecologia - UFJF" (PGECOLUFJF) and "Programa de Pós-Graduação em Ciências Farmacêuticas - UFJF" for the financial support.

\section{RESUMO}

Este trabalho compara duas espécies medicinais de $\mathrm{Ka}$ lanchoe utilizadas muitas vezes de forma indiferenciada pela população, quanto à distribuição de antocianinas sob influência de quatro níveis de luminosidade por 6 meses. Para a análise morfoanatômica foi seccionado o $6^{\circ}$ nó do caule de cada planta. Testes histoquímicos clássicos evidenciaram a presença de antocianinas em cortes transversais dos caules, pecíolos e lâminas foliares. Os pecíolos e lâminas foliares foram submetidos à extração com metanol acidificado e as antocianinas foram quantificadas através de leituras espectrofotométricas. Observou-se em nível macroscópico nas duas espécies, maior presença de antocianinas nos caules e pecíolos das plantas sob luz plena. A microscopia de caules de $K$. brasiliensis evidenciou a deposição de antocianinas no tecido subjacente à epiderme e córtex, o que aumentou com a intensidade luminosa. Em $K$. pinnata, observou-se colênquima subepidérmico, o que interferiu na visualização de antocianinas. Nos pecíolos e lâminas foliares de $K$. brasiliensis, a deposição de antocianinas foi periférica e em $K$. pinnata, se deu também por todo o córtex. A quantificação de antocianinas dos pecíolos mostrou, em $70 \%$ de luminosidade, teores superiores aos obtidos em $25 \%$, porém nas lâminas foliares não foram obtidos resultados significativos. Este trabalho contribui para a farmacognosia de Kalanchoe e sustenta-se pela descrição de flavonóides como marcadores biológicos do gênero.

Palavras-chave: Antocianinas, Kalanchoe, luminosidade, anatomia vegetal.

\section{REFERENCES}

Castañeda - Ovando A, Pacheco-Hernández ML, Páez HERNÁNDEZ ME, RODRÍGUEZ JA AND GALÁN-VIDAL CA. 2009. Chemical studies of anthocyanins: A review. Food Chem 113: 859-871.

Costa SS, Muzitano MF, CAMARGo LMM AND COUTINHO MAS. 2008. Therapeutic Potential of Kalanchoe species: Flavonoids and other Secondary Metabolites. Nat Prod Com 3: 2151-2164.

CRUZ APG. 2008. Avaliação do efeito da extração e da microfiltração do açaí sobre sua composição e atividade antioxidante, Mr. Thesis, Rio de Janeiro: Universidade Federal do Rio de Janeiro, p.10-11. (Unpublished).

Cruz BP, Chedier LM, Fabri RL AND Pimenta DS. 2011. Chemical and agronomic development of Kalanchoe brasiliensis Camb. and Kalanchoe pinnata (Lamk.) Pers under light and temperature levels. An Acad Bras Cienc 83: $1435-1441$

GobBo-Neto L AND LOPES NP. 2007. Plantas medicinais: Fatores de influência no conteúdo de metabólitos secundários. Quim Nova 30: 374-381.

HE J AND GIUSTI MM. 2010. Anthocyanins: natural colorants with health-promoting properties. Annu Rev Food Sci Technol 1: 163-187.

KONG J-M, CHIA L-S, GOH N-K, CHIA T-F AND BROUILLARD R. 2003. Analysis and biological activities of anthocyanins. Phytochemistry 64: 923-933.

KRAUS JE AND ARDUIN M. 1997. Manual básico de métodos em morfologia vegetal, Seropédica: Editora Universidade Rural.

Kuskoski EM, Asuero AG, Morales MT and Fett R. 2006. Frutos tropicais silvestres e polpas de frutas congeladas: atividade antioxidante, polifenóis e antocianinas. Cienc Rural 36: 1283-1287.

Lima VLAG, MÉlo EA, MACIEL MIS AND Lima DES. 2003. Avaliação do teor de antocianinas em polpa de acerola congelada proveniente de frutos de 12 diferentes aceroleiras (Malpighia emarginata D.C.). Cienc Tecnol Aliment 23: 101-103

LORENZI H AND MATOS FJA. 2008. Plantas medicinais no Brasil: Nativas e Exóticas, $2^{\text {nd }}$ ed., Nova Odessa: Instituto Plantarum, p. 223-224.

MANCINELLI AL. 1990. Interaction between light quality and light quantity in the photoregulation of anthocyanin production. Plant Physiol 92: 1191-1195.

MotA RV. 2006. Caracterização do suco de amora-preta elaborado em extrator caseiro. Cienc Tecnol Aliment 26: 303-308.

Silva GDF, Silva SRS, BARbosa LCA, DuARTE LP, RIBEIRO SMR, QUEIROZ JH, VIEIRA FILHO AS AND OLIVEIRA MLR. 2009. Antioxidant activity of Maytenus imbricata Mart., Celastraceae. Rev Bras Farmacogn 19: 530-536. 
Steyn WJ, Wand SJE, Holcroft DM AND Jacobs G. 2002. Anthocyanins in vegetative tissues: a proposed unified function in photoprotection. New Phytologist 155: 349-361.

TORSKANGERPOLL K AND ANDERSEN ØM. 2005. Colour stability of anthocyanins in aqueous solutions at various pH values. Food Chem 89: 427-440.
VEIGA JR VF. 2005. Kalanchoe brasiliensis Camb. e Kalanchoe pinnata (Lamk.) Pers. In: Amaral ACF et al., Coletânea científica de plantas de uso medicinal, Rio de Janeiro: Editora FIOCRUZ, p. 103-124. 